\title{
Antidiabetic and Nephroprotective Activity of Hedychium spicatum in Streptozotocin-Induced Diabetic Rats
}

\author{
Roopal Mittal $^{1,2, *}$, Ankita Beniwal ${ }^{3}$ \\ ${ }^{1}$ R.K.S.D. College of Pharmacy, Ambala Road, Kaithal (Haryana) 136027, India; \\ ${ }^{2}$ Research Scholar, IKG Punjab Technical University, Jalandhar (Punjab) 144601,India; \\ ${ }^{3}$ Patient Safety Pharmacovigilance Associate, ADR-Monitoring Centre-KCGMC Karnal (Haryana) 132001, India.
}

\section{ARTICLE INFO:}

Received: 19 Nov 2020

Accepted: 22 Dec 2020

Published: 30 Dec 2020

\section{Corresponding author *}

Roopal Mittal,

R.K.S.D. College of Pharmacy, Ambala Road, Kaithal (Haryana) 136027, India;

Research Scholar, IKG Punjab Technical University, Jalandhar (Punjab) 144601, India;

E Mail: roopmittal17@gmail.com

\begin{abstract}
:
Objective: Diabetic Nephropathy, an end-stage renal disease clinically manifested as progressively increased proteinuria accompanied by increased blood pressure. Histologically, Diabetic Nephropathy is characterised by diffuse or nodular glomerulosclerosis, tubuleinterstitial fibrosis and atrophy. The aim of this study was to identify either the ethanolic extract posses an antidiabetic activity and ameliorate effect on diabetes-induced nephropathy or not.

Material and method: In-vitro alpha-amylase inhibitory assay and oral glucose tolerance tests were carried out before the induction of diabetes. Fasting blood glucose was measured at different time intervals to check the hyperglycaemic state. On the $40^{\text {th }}$ day of the study, the urine sample was collected from metabolic cages and venous blood samples were obtained and used for determination of various biochemical parameters. In the end, histopathological studies were carried for checking the preventative effect on kidneys.

Result: The In-Vitro a-Amylase inhibitory assay results revealed that the ethanolic extracts were found to have significant inhibitory potential as compared to acarbose. Further the OGTT, Serum BUN, creatine, lipid peroxidation, lipid profile except High Density Lipoprotein$\mathrm{C}$ and anti-oxidant were found to be decreased in a dose-dependent manner, marked effect in Group VII $(50 \%$ extract of $100 \mathrm{mg} / \mathrm{kg}$ and $50 \%$ of standard dose). In histopathology, Group VI and VII prevented degeneration of nephrons in the kidney and maintained the normal cellular size of nephrons.

Conclusion: The ethanolic extract posses a significant activity to lower the blood glucose level as well protect the renal damage.
\end{abstract}

Keywords: Diabetic nephropathy, anti-oxidant, lipid peroxidation, Oral Glucose Tolerance Test, Histopathology.

\section{INTRODUCTION}

Diabetes mellitus (DM) is a syndrome of disordered metabolism of carbohydrates, proteins and fats. In the layman's language, this disease is termed as 'Diabetes'. It results in abnormally high blood sugar level i.e. hyperglycemia and is caused by a combination of environmental and hereditary factors [1]. Diabetes now a day has widely spread all over the world and $5 \%$ of the population is suffering from it. In its impact, it has now become more deadly than Acquired Immunodeficiency Syndrome if we see the number of deaths caused by its worldwide is 246 million [2].

Diabetic Nephropathy (DN) is a key basis of end-stage renal disease. Clinically, it can be defined as progressively increased proteinuria accompanied by increased blood pressure and impaired glomerular filtration [3]. Histologically, DN is characterised by diffuse or nodular glomerulosclerosis, tubule-interstitial fibrosis and atrophy [4]. The continuous rise in blood sugar levels will induce to renal, retinal and neuronal damage as secondary complications. Intracellularly hyperglycaemia causes activation of protein kinase $\mathrm{C}$, increased end products of advanced glycosylation and diacylglycerol synthesis. The glomerular hyperfilteration, microalbuminurea and shear strain appeard to be the consequent haemodynamic alterations [5].

The Hedychium spicatum (Zingiberaceaeae) is a rhizomatous medicinal plant widely known for its economic, aesthetic and aromatic properties. The rhizome part contain essential oil, diarylheptanoids, starch, resin, organic acids, glycosides, albumen and saccharides, which has been advocated for 
International Journal of Pharma Research and Health Sciences, 2020; 8 (6): 3256-3261

blood purification. The essential oil from rhizome showed the presence of cineole, terpinene, limonene, phellandrene, p-cymene, linalool and terpeneol as major constituents which are shown to be effective in treating diabetes [6]. The rhizome is generally known for its medicinal properties [7, 8]. The rhizome had been described to possess antiinflammatory, anti-asthmatic, hypo-glycaemia, vasodilator, spasmolytic, hypotensive, in-vitro pediculicidal, cytotoxic, anti-microbial properties [9], hypoglycaemic and also preliminary studies done by researchers had indicated the antidiabetic activity of the plant $[10,11]$. Keeping all the above points in view it was decided to evaluate it for antidiabetic activity and ameliorative effect in diabetic nephropathy.

\section{MATERIAL AND METHODS}

Drugs and chemicals: Streptozotocin, a drug was available with USA (San Diego) based pharma company Calbiochem EMD chemicals, Germany based Convergent Technologies (GmbH \& Co. KG) does have Elegance CT-X10 Sugar Monitor, Ambala based Oyster Pharma gifted a sample of Metformin (standard drug) and Rankem Pvt. Ltd, New Delhi based provided us the analytical grade solvents.

Procurement of plant raw material: Fresh aerial parts of $H$. spicatum were collected from Khari Baoli, Delhi and were dried and coarsely powdered using a grinder. Authentication and identification of plant were done by Dr. H B Singh at National Institute of Science Communication And Information Resources (NISCAIR), New Delhi, and voucher specimen no. IPS/012/578 was submitted for future reference.

Preparation of extract: Shade dried coarsely powdered rhizomes of $H$. spicatum were packed in soxhlet extractor and a sufficient volume of solvent was added to the reservoir, and the hot continuous extraction process was continued for about 48 hours or until solvent coming down from the siphoning tube became colorless, firstly the powdered drug was treated with petroleum ether $\left(60-80^{\circ} \mathrm{C}\right)$ and then with alcohol (ethanol). A Rotatory vacuum evaporator was used to distil excess alcohol under reduced pressure. A brown residue was recovered from the flask with $48.17 \%$ yield and was stored in the refrigerator to use for further pharmacological studies.

Phytochemical screening: Petroleum ether and ethanolic extract obtained from soxhlet apparatus were subjected to screening for the presence of various phytoconstituents such as alkaloid, carbohydrate, flavonoid, proteins, amino acids, phenols, tannins, glycosides, and steroids [12, 13, 14].

Animals: Wistar albino rats (150-250g) and Swiss albino mice (20-25g) of either sex, brought from National Institute of Pharmaceutical Education and Research, Mohali, were kept in the Animal House of Institute of Pharmaceutical Sciences, Kurukshetra University, Kurukshetra. Animals were housed at standard conditions of temperature (22 \pm $1 \circ \mathrm{C})$ and $12 / 12 \mathrm{~h}$ light/dark cycle. Permission for the conduct of these experiments was obtained from Institutional Animal Ethics Committee (IAEC) of CPCSEA vide no. IPS/AH/657/199. The animals were acclimatized to laboratory conditions for $48 \mathrm{~h}$ before starting the experiment. Animals were provided a standard rodent pellet diet and the food was withdrawn $18-24 \mathrm{~h}$ before the experiment was conducted.

In-Vitro $\alpha$-Amylase Inhibitory Activity: The $\alpha$-amylase inhibitory assay was adapted and modified from Giancarlo $e t$ al [15]. The Starch solution $(0.5 \% \mathrm{w} / \mathrm{v})$ and enzyme solution (0.5 unit $/ \mathrm{ml})$ were prepared accordingly stated in the procedure. Then petroleum ether and ethanolic extracts were dissolved in DMSO to give different concentrations (10, 20 $40,60,80,100 \mathrm{mg} / \mathrm{ml})$. The absorbance value was determined at $540 \mathrm{~nm}$ in a UV-Visible Spectrophotometer (Double beam). The solution of acarbose (at the concentrations of $10,20,40,60,80,100 \mu \mathrm{g} / \mathrm{ml}$ ) was used as the positive control. The $\alpha$-amylase inhibitory activity was expressed as percent inhibition and was calculated using the equation given below: The $\% \quad \alpha$-amylase inhibition was plotted against the extract concentration and the $\mathrm{IC}_{50}$ values were obtained from the graph.

$\% \mathrm{I}_{\alpha \text {-amylase }}$ inhibition $=100 \times\left(\Delta \mathrm{A}_{\text {control }}-\Delta \mathrm{A}_{\text {sample }}\right) / \Delta \mathrm{A}$

$$
\begin{aligned}
& \text { Where } \mathrm{A}_{\text {Control }}=\mathrm{A}_{\text {Test }}-\mathrm{A} \\
& \text { and } \mathrm{A}_{\text {Sample }}=\mathrm{A}_{\text {Test }}-\mathrm{A}_{\text {Blank }}
\end{aligned}
$$

\section{Pharmacological Studies}

Acute Toxicity Study: Toxicity studies were conducted as per internationally accepted protocol drawn under OECD guidelines 425 in Swiss albino mice [16].

Oral Glucose Tolerance Test (OGTT): The OGTT for nondiabetic rats were performed according to the standard method [16]. Animals were divided into five groups, each group consisting of six animals. All the groups were starved for 16 hours before starting the experiment. Group I (received vehicle) acted as a normal control group. Group II (received metformin (150 mg/kg body weight)) acted as Standard. Group III to V (received ethanolic extracts at the dose of $100,300,500 \mathrm{mg} / \mathrm{kg}$ body weight) acted as test groups. To start the experiment, the ethanolic extract and standard drug were then administered orally to the glucose fed ( $2 \mathrm{~g} / \mathrm{kg}$ body weight) rats. Serum glucose of blood sample was estimated from the tail vein by using glucometer (Elegance CT-X10 sugar monitor (Germany) at 0, 30, 60, 90 and 120 minutes. Mean \pm standard error of mean (SEM) was used to express data.

Induction of diabetes mellitus: The diabetes was induced experimentally in rats by a single intraperitoneal injection of a freshly prepared solution of STZ (dissolve in citrate buffer $0.1 \mathrm{~mol} / \mathrm{L}, \mathrm{pH} 4.2$ ) at a dose of $60 \mathrm{mg} / \mathrm{kg}$ body weight for three successive days. The rats were considered diabetic if blood glucose concentration increased up to 200 or more 
International Journal of Pharma Research and Health Sciences, 2020; 8 (6): 3256-3261

$\mathrm{mg} / \mathrm{dl}$. The Streptozotocin-induced diabetic rats were stabilized in diabetic condition for 7 days.

Experimental design: The rats used for the study were divided into seven groups, where each group consisted of ten animals. Group I served as normal control (received normal saline); Group II treated as diabetic control (received STZ for successive three days); Group III was treated with metformin $(150 \mathrm{mg} / \mathrm{kg})$ after induction of diabetes and Group IV, V and VI received ethanolic H. spicatum extract at a dose level of 100, 300 and $500 \mathrm{mg} / \mathrm{kg}$, and Group VII received $50 \%$ extract of $100 \mathrm{mg} / \mathrm{kg}$ and $50 \%$ of standard dose were administered orally for 40 days. At the end of the experimental period, the animals fasted overnight and blood was collected for further various biochemical estimations and histopathological studies.

Biochemical estimation: The fasting blood glucose was measured at different time intervals to check the hyperglycaemic state. On the $39^{\text {th }}$ day of the study, individual rats were placed in metabolic cages to collect $24 \mathrm{~h}$ urine for measurement of urinary albumin. On the $40^{\text {th }}$ day of the study, venous blood samples were obtained from the retro-orbital vein and used for determination of serum creatinine, Blood Urea Nitrogen (BUN) and lipid profile. These parameters were analysed by using the diagnostic kit (ERBA Diagnostics Mannheim, Germany). Serum glucose was measured with the Elegance CT-X10 sugar monitor (Germany) [18, 19]. For the estimation of protein, Glutathione (GSH), Superoxide dismutase (SOD), Catalase peroxidise (CAT) and malondialdehyde (MDA). The rats were sacrificed by cervical dislocation. Kidneys were removed, and washed (physiological saline), fatty tissue was removed and weighed. They were homogenized in ice-cold $20 \mathrm{mM}$ Tris- $\mathrm{HCl}$ buffer ( $\mathrm{pH} 7.4)$ and the homogenates were then centrifuged at $10,000 \mathrm{~g}$ for $10 \mathrm{~min}$ at $4^{\circ} \mathrm{C}$ [20]. The grouped rat's kidney was collected. Later on, the sectioned tissue was fixed in $10 \%$ formalin immediately after removal from the animal to avoid decomposition. Then the tissues were embedded in paraffin wax and were stained with hematoxylin-eosin for histopathological studies. They were then treated with biphenyl xylene and examined under a microscope. All sections were evaluated for the degree of tubular, glomerular injury and necrosis [21].

Statistical analysis: Statistical comparisons were performed by one-way ANOVA followed by Dunnett's t-Test and the values were considered statistically significant when $\mathrm{P}<0.05$. Statistical calculations and the graphs were prepared using Graph Pad instat version 3.10 for Windows (Graph Pad Software, San Diego, CA, USA, www.graphpad.com).

\section{RESULTS}

The ethanolic extract of $H$. spicatum rhizome showed carbohydrates, steroids, alkaloids, glycosides, flavonoids, tannins, and triterpenoids are visible in the preliminary phytochemical studies results. The acute toxicity test of ethanolic extract of the plant $H$. spicatum was found to be safe at the dose of $5000 \mathrm{mg} / \mathrm{kg}$ according to OECD guidelines 425 . Further, the ethanolic extracts of $H$. spicatum rhizome were observed to be active in lowering the postprandial blood glucose level in oral glucose tolerance test. The results in Table 1 suggested that the ethanolic extracts of $H$. spicatum may be useful in the treatment of impaired glucose levels. Additionally, the oral glucose tolerance test significance over the normal blood sugar monitoring is used to diagnose pre-diabetes and diabetic prone individuals [22]. The $\alpha$-amylase inhibitory studies performed demonstrated that the ethanolic extracts of $H$. spicatum were found to have significant inhibitory potential. Besides, it was observed that ethanolic extract exhibited appreciable alpha-amylase inhibitory effects $\left(\mathrm{IC}_{50}=54 \mu \mathrm{g} / \mathrm{ml}\right)$ when compared with acarbose $\left(\mathrm{IC}_{50}=40 \mu \mathrm{g} / \mathrm{ml}\right)$ as shown in Table 2 .

Table 1: Effect of $\boldsymbol{H}$. spicatum extract in Oral Glucose Tolerance Test

\begin{tabular}{|c|c|c|c|c|c|c|}
\hline Groups & Dose & 0 min & $30 \mathrm{~min}$ & $60 \mathrm{~min}$ & $90 \mathrm{~min}$ & $120 \mathrm{~min}$ \\
\hline Group I & $\begin{array}{l}0.9 \% \\
\text { Saline }\end{array}$ & $\begin{array}{c}90.83 \pm 0 . \\
94\end{array}$ & $134 \pm 2.01$ & $160.17 \pm 1.30$ & $118.5 \pm 0.76$ & $75 \pm 1.23$ \\
\hline $\begin{array}{c}\text { Group } \\
\text { II }\end{array}$ & $\begin{array}{c}150 \mathrm{mg} \\
/ \mathrm{kg} \\
\text { Metfor } \\
\text { min }\end{array}$ & $\begin{array}{c}71.00 \pm 1 \\
06 \mathrm{a}^{1} \\
\end{array}$ & $\begin{array}{c}106.17 \pm 3.6 \\
6 a^{1}\end{array}$ & $120.67 \pm 1.22 \mathrm{a}$ & $\begin{array}{c}100.17 \pm 0.7 \\
9 a^{1}\end{array}$ & $\begin{array}{c}65.33 \pm 1.22 \\
\mathrm{a}^{1}\end{array}$ \\
\hline $\begin{array}{c}\text { Group } \\
\text { III }\end{array}$ & $\begin{array}{c}100 \mathrm{mg} \\
/ \mathrm{kg}\end{array}$ & $\begin{array}{l}83.50 \pm 1 \\
05 \mathrm{a}^{1}, \mathrm{~b}^{1}\end{array}$ & $\begin{array}{c}114.5 \pm 1.40 \\
\mathrm{a}^{1}\end{array}$ & $\begin{array}{c}140.17 \pm 1.24 \\
\mathrm{a}^{1}, \mathrm{~b}^{1}\end{array}$ & $\begin{array}{c}108.5 \pm 1.11 \\
\mathrm{a}^{1}\end{array}$ & $\begin{array}{c}66.66 \pm 1.22 \\
a^{1},\end{array}$ \\
\hline $\begin{array}{l}\text { Group } \\
\text { IV }\end{array}$ & $\begin{array}{c}300 \mathrm{mg} \\
/ \mathrm{kg}\end{array}$ & $\begin{array}{l}80.83 \pm 0 . \\
87 \mathrm{a}^{1}, \mathrm{~b}^{1}\end{array}$ & $\begin{array}{c}111.67 \pm 2.1 \\
2 \mathrm{a}^{1}\end{array}$ & $\begin{array}{c}129.33 \pm 1.08 \mathrm{a} \\
1, \mathrm{~b}^{1}\end{array}$ & $104 \pm 1.23 \mathrm{a} 2$ & $\begin{array}{c}72.16 \pm 1.51 \\
b^{1}\end{array}$ \\
\hline $\begin{array}{c}\text { Group } \\
\mathrm{V}\end{array}$ & $\begin{array}{c}500 \mathrm{mg} \\
/ \mathrm{kg}\end{array}$ & $\begin{array}{c}72.5 \pm 0.7 \\
6 \mathrm{a}^{1}\end{array}$ & $\begin{array}{c}112.67 \pm 1.7 \\
8 \mathrm{a}^{1}\end{array}$ & $119.5 \pm 1.76 \mathrm{a}^{1}$ & $\begin{array}{c}89.33 \pm 1.35 \\
\mathrm{a}^{1}\end{array}$ & $73.5 \pm 1.55$ \\
\hline
\end{tabular}

(The above data were expressed by means \pm SEM of six rats /group a1: significantly different from control group; b1: significantly different from metformin group, using one-way ANOVA with Dunnett's t-test at $\mathrm{P}<$ 0.01 ;

a2: significantly different from control group; b2: significantly different from metformin group, using one-way ANOVA with Dunnett's t-test at $\mathrm{P}<0.05$.)

Table 2: Effect of Hedychium spicatum extract in in-vitro alpha amylase assay

\begin{tabular}{|c|c|c|c|}
\hline $\begin{array}{c}\text { Concentration } \\
\text { in } \mu \mathrm{g} / \mathrm{ml}\end{array}$ & $\begin{array}{c}\text { \%age inhibition of } \\
\text { pet. ether extract }\end{array}$ & $\begin{array}{c}\text { \%age inhibition of } \\
\text { ethanolic extract }\end{array}$ & $\begin{array}{c}\text { \%age inhibition } \\
\text { of Acarbose }\end{array}$ \\
\hline 10 & 15.13 & 20.33 & 30.98 \\
\hline 20 & 33.76 & 37.23 & 40.87 \\
\hline 40 & 24.67 & 42.56 & 45.78 \\
\hline 60 & 43.34 & 58.54 & 60.92 \\
\hline 80 & 58.72 & 63.98 & 65.34 \\
\hline 100 & 62.89 & 65.03 & 73.76 \\
\hline
\end{tabular}

In Biochemical parameters, the Serum blood urea nitrogen (BUN) and creatinine were significantly elevated in the diabetic group as compared to that of control and $H$. spicatum treated rats. Initially, the plasma BUN and creatinine level in diabetic (group II) animals were found to be high as compared to control rats (group I). 
International Journal of Pharma Research and Health Sciences, 2020; 8 (6): 3256-3261

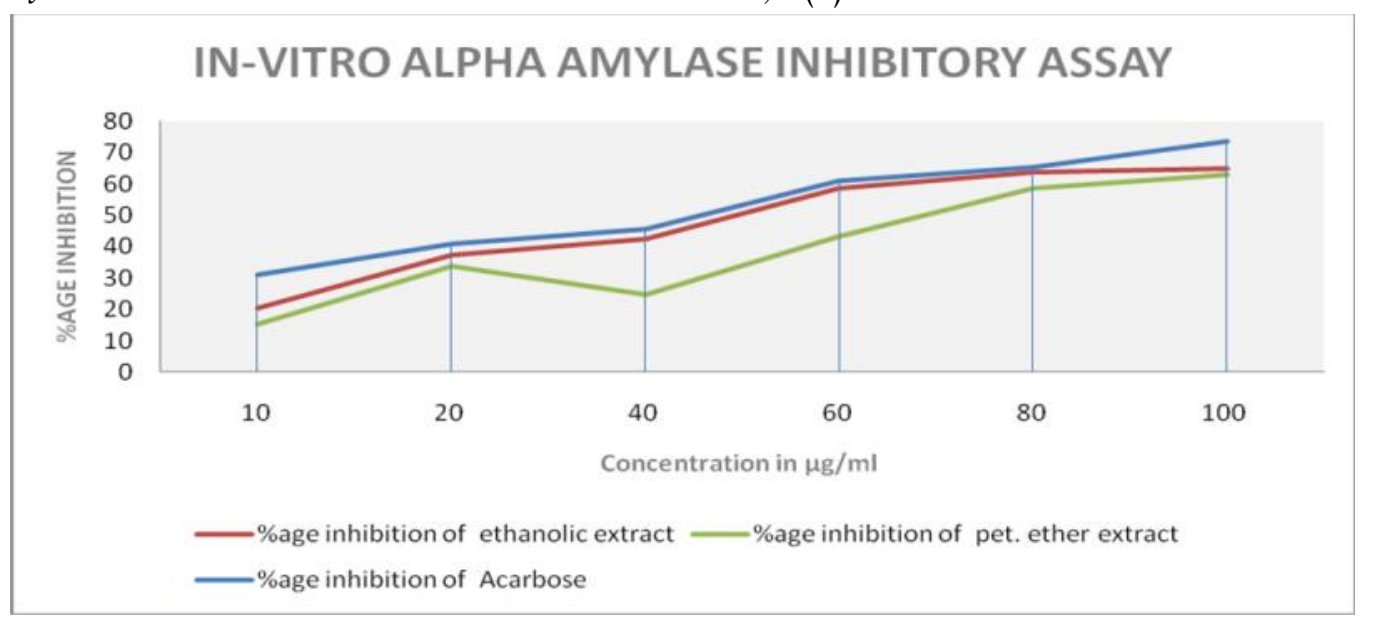

Graph 1: Effect of $\boldsymbol{H}$. spicatum extracts in in-vitro alpha amylase inhibition assay.

Table 3: Change in biochemical parameters after 40 days of $\boldsymbol{H}$. spicatum extract administration in diabetic rats.

\begin{tabular}{|c|c|c|c|c|c|c|c|}
\hline Parameters & Group I & Group II & Group III & Group IV & Group V & Group VI & Group VII \\
\hline $\mathrm{BUN}(\mathrm{mg} / \mathrm{dl})$ & $17.58 \pm 0.20$ & $51.01 \pm 0.55 \mathrm{a}^{1, \mathrm{a}^{2}}$ & $20.06 \pm 0.48 \mathrm{a}^{1}$ & $33.90 \pm 0.40 \mathrm{a}^{1}, \mathrm{~b}^{1}$ & $28.30 \pm 0.59 \mathrm{a}^{1}, \mathrm{~b}^{1}$ & $25.24 \pm 0.73 \mathrm{a}^{1}, \mathrm{~b}^{1}$ & $24.61 \pm 1.01 \mathrm{a}^{1}, \mathrm{~b}^{1}$ \\
\hline $\begin{array}{l}\text { Creatinine } \\
(\mathrm{mg} / \mathrm{dl})\end{array}$ & $1.04 \pm 0.04$ & $11.53 \pm 0.89 \mathrm{a}^{1}$ & $2.13 \pm 0.11$ & $7.15 \pm 0.09 a^{1}, b^{1}$ & $5.33 \pm 0.23 \mathrm{a}^{1}, \mathrm{~b}^{1}$ & $4.53 \pm 0.26 \mathrm{a}^{1}, \mathrm{~b}^{1}$ & $1.23 \pm 0.07 \mathrm{~b}^{2}$ \\
\hline Urinary albumin & $0.12 \pm 0.07$ & $0.37 \pm 0.02 \mathrm{a}^{1}$ & $0.10 \pm 0.01 \mathrm{a}^{1}$ & $0.22 \pm 0.01 \mathrm{a}^{1}$ & $0.21 \pm 0.03 \mathrm{a}^{2}, \mathrm{~b}^{2}$ & $0.15 \pm 0.01 \mathrm{~b}^{1}$ & $0.10 \pm 0.01 b^{1}$ \\
\hline $\begin{array}{l}\text { Total cholesterol } \\
(\mathrm{mg} / \mathrm{dl})\end{array}$ & $94.33 \pm 0.98$ & $192.33 \pm 1.05 \mathrm{a}^{1}$ & $102.67 \pm 1.80 \mathrm{a}^{1}$ & $122.17 \pm 2.84 \mathrm{a}^{1}, \mathrm{~b}^{1}$ & $113.50 \pm 1.23 \mathrm{a}^{1}, \mathrm{~b} 1$ & $105.67 \pm 1.05 \mathrm{a}^{1}$ & $99.83 \pm 0.94$ \\
\hline $\begin{array}{l}\text { HDL-C } \\
(\mathrm{mg} / \mathrm{dl})\end{array}$ & $41.50 \pm 0.76$ & $15.50 \pm 0.88 \mathrm{a}^{1}$ & $47.80 \pm 0.70 \mathrm{a}^{1}$ & $19.83 \pm 0.98 \mathrm{a}^{1}, \mathrm{~b}^{1}$ & $30.00 \pm 1.29 \mathrm{a}^{1}, \mathrm{~b}^{1}$ & $38.67 \pm 0.91 \mathrm{~b}^{1}$ & $47.00 \pm 0.73 \mathrm{a}^{1}, \mathrm{~b}^{1}$ \\
\hline TG $(\mathrm{mg} / \mathrm{dl})$ & $81.50 \pm 0.61$ & $144.80 \pm 1.13 \mathrm{a}^{1}$ & $84.50 \pm 1.53 \mathrm{a}^{1}$ & $120.50 \pm 1.91 \mathrm{a}^{1}, \mathrm{~b}^{1}$ & $97.50 \pm 2.75 \mathrm{a}^{1}$ & $92.5 \pm 0.76 \mathrm{a}^{1}, \mathrm{~b}^{1}$ & $83.00 \pm 0.57 \mathrm{a}^{1}, \mathrm{~b}^{1}$ \\
\hline $\begin{array}{l}\text { LDL- } \\
\text { C(mg/dl) }\end{array}$ & $35.00 \pm 0.93$ & $89.50 \pm 0.67 \mathrm{a}^{1}$ & $33.00 \pm 1.45$ & $62.83 \pm 1 . \mathrm{a}^{1}, \mathrm{~b}^{1}$ & $58.00 \pm 1.09 \mathrm{a}^{1}, \mathrm{~b}^{1}$ & $44.16 \pm 0.78 \mathrm{a}^{1}, \mathrm{~b}^{1}$ & $33.16 \pm 1.19 \mathrm{a}^{1}, \mathrm{~b}^{1}$ \\
\hline
\end{tabular}

(The above data were expressed by means \pm SEM of six rats /group

a1: significantly different from control group; b1: significantly different from metformin group, using one-way ANOVA with Dunnett's t-test at $\mathrm{P}<0.01$; a2: significantly different from control group; b2: significantly different from metformin group, using one-way ANOVA with Dunnett's t-test at $P<0.05$.).

The administration of the ethanolic extract to diabetic rats resulted in a significant decrease of plasma BUN level in comparison to that obtained from diabetic group rats (group II). Serum cholesterol, LDL-C, and triglycerides (TG) levels of the diabetic group were significantly higher while HDL-C was lower in diabetic rats as compared to the control one. However, administration of $H$. spicatum significantly improved these parameters in a dose-dependent manner as shown in Table 3. Also, the urinary albumin excretion was significantly increased in the diabetic group (group II) as compared to the control (group I) in Table 3. H. spicatum extract in a dose of $500 \mathrm{mg} / \mathrm{kg}$ body weight showed a marked reduction of urinary albumin level. MDA concentration in the kidney of diabetic group significantly increased in comparison to the control animals (Table 4). The elevated MDA level in the kidney of the diabetic showed a significant decrease in Group VII markedly. GSH levels and antioxidant enzyme activities (CAT and SOD) in the kidney of the control and tested groups were shown in Table 4. Concentration in the kidney of these antioxidant parameters in the diabetic group significantly decreased in comparison to the control group.

Table 4: Effect of $\boldsymbol{H}$. spicatum extract on antioxidant parameters in renal tissue

\begin{tabular}{|c|c|c|c|c|c|c|c|}
\hline Parameters & Group I & Group II & $\begin{array}{c}\text { Group } \\
\text { III }\end{array}$ & $\begin{array}{l}\text { Group } \\
\text { IV }\end{array}$ & $\begin{array}{c}\text { Group } \\
\text { V }\end{array}$ & $\begin{array}{l}\text { Group } \\
\text { VI }\end{array}$ & $\begin{array}{c}\text { Group } \\
\text { VII }\end{array}$ \\
\hline $\begin{array}{l}\text { MDA(nmoles } \\
\text { /mg protein) }\end{array}$ & $\begin{array}{c}0.04 \pm 0 . \\
02\end{array}$ & $\begin{array}{c}15.88 \pm 0 \\
34 \mathrm{a}^{1}\end{array}$ & $\begin{array}{c}0.07 \pm 0 . \\
003\end{array}$ & $\begin{array}{c}13.072 \pm \\
0.48 \\
1,{ }^{1} \\
\mathrm{a}^{2} \mathrm{~b}\end{array}$ & $\begin{array}{c}8.028 \pm \\
.38 \\
a^{1}, b^{1}\end{array}$ & $\begin{array}{c}5.935 \pm 0 \\
.37 \\
1{ }^{1}, b^{1}\end{array}$ & $\begin{array}{c}3.43 \pm 0 \\
25 \\
\mathrm{a}^{1}, \mathrm{~b}^{1}\end{array}$ \\
\hline $\begin{array}{c}\text { GSH( } \\
\text { moles/ } \\
\text { mg protein }\end{array}$ & $\begin{array}{c}1.808 \pm 0 \\
.04\end{array}$ & $\begin{array}{c}0.25 \pm 0.0 \\
1 \\
1\end{array}$ & $\begin{array}{c}1.67 \pm 0 \\
05 \mathrm{a}^{1}\end{array}$ & $\begin{array}{l}0.43 \pm 0.0 \\
08 \mathrm{a}^{1}, \mathrm{~b}^{1}\end{array}$ & $\begin{array}{c}0.64 \pm 0 \\
09 \\
a^{1}, b^{1}\end{array}$ & $\begin{array}{c}0.81 \pm 0 . \\
03 \\
a^{1}, b^{1}\end{array}$ & $\begin{array}{c}0.97 \pm 0 . \\
02 \\
a^{1}, b^{1}\end{array}$ \\
\hline $\begin{array}{l}\text { SOD(uni } \\
\text { ts/mg } \\
\text { protein) }\end{array}$ & $\begin{array}{c}44.53 \pm 1 \\
.23\end{array}$ & $\begin{array}{c}12.75 \pm 0 \\
27 \mathrm{a}^{1}\end{array}$ & $\begin{array}{c}42.28 \pm 0 \\
.24\end{array}$ & $\begin{array}{c}18.29 \pm 0 \\
29 \\
\mathrm{a}^{1}, \mathrm{~b}\end{array}$ & $\begin{array}{c}23.59 \pm \\
.73 \\
a^{1}, b^{1}\end{array}$ & $\begin{array}{c}27.04 \pm 0 \\
.18 \\
\mathrm{a}^{1}, \mathrm{~b}^{1}\end{array}$ & $\begin{array}{c}31.59 \pm 1 \\
.48 \\
\mathrm{a}^{1}, \mathrm{~b}^{1}\end{array}$ \\
\hline $\begin{array}{l}\text { CAT ( moles } \\
\text { of } \mathrm{H}_{2} \mathrm{O}_{2} / \mathrm{min} /\end{array}$ & $\begin{array}{c}2.85 \pm 0 \\
13\end{array}$ & $0.92 \pm 0.0$ & $1.86 \pm 0$. & $\begin{array}{c}1.10 \pm 0.0 \\
3\end{array}$ & $\begin{array}{c}1.25 \pm 0 \\
05\end{array}$ & $1.66 \pm 0$. & $\begin{array}{c}1.70 \pm 0 . \\
02\end{array}$ \\
\hline
\end{tabular}

IIIIIIIIC International Journal of Pharma Research and Health Sciences. All rights reserved 


\begin{tabular}{|l|l|l|l|l|l|l|l|}
\hline mgprotein) & $1 \mathrm{a}^{1}$ & $04 \mathrm{a}^{1}$ & $\mathrm{a}^{1}, \mathrm{~b}^{1}$ & $\mathrm{a}^{1}, \mathrm{~b}^{1}$ & $07 \mathrm{a}^{1}$ & $\mathrm{a}^{1}$ \\
\hline
\end{tabular}

(The above data were expressed by means \pm SEM of six rats /group a1: significantly different from control group; b1: significantly different from metformin group, using one-way ANOVA with Dunnett's t-test at $\mathrm{P}<$ 0.01 ;

a2: significantly different from control group; b2: significantly different from metformin group, using one-way ANOVA with Dunnett's t-test at $\mathrm{P}<0.05$.)

Histopathological studies: In normal kidney cross section, a healthy glomeruli and healthy cells in spherical shape and granulated cytoplasm was found to be present as compared to the diabetic control, which showed the ruptured, destructive glomeruli, accompanied with swollen distorted cell wall and a number of vacuoles. The group III having treatment with standard showed a number of glomeruli preserved, less swelling with regenerating cell wall accompanied with decreased in vacuolar size. The group IV, $\mathrm{V}$ and VI showed secure glomeruli in circular and oval shaped cells, granular cytoplasm, regenerated cell wall and intermediate vacuoles. The ethanolic extracts of $H$. spicatum (300 mg/ kg and $500 \mathrm{mg} / \mathrm{kg}$ ) prevented the degeneration of nephrons in the kidney and maintain the normal cellular size of the nephron in a dose-dependent manner. The group VII having $500 \mathrm{mg} / \mathrm{kg}$ of Hedychium spicatum and metformin showed highest efficacy with several glomeruli in safe and preventative effect showing oval shaped cells, granular cytoplasm, regenerated cell wall and intermediate vacuoles. Along with this, the histopathological studies of untreated diabetic rats showed almost destruction of glomerular cells due to uncontrolled diabetes whereas the diabetic rats which were treated with ethanolic extract of $H$. spicatum showed almost normal cells at a high dose. Thus the medicinal herb could be an adjuvant to existing antidiabetic therapies.

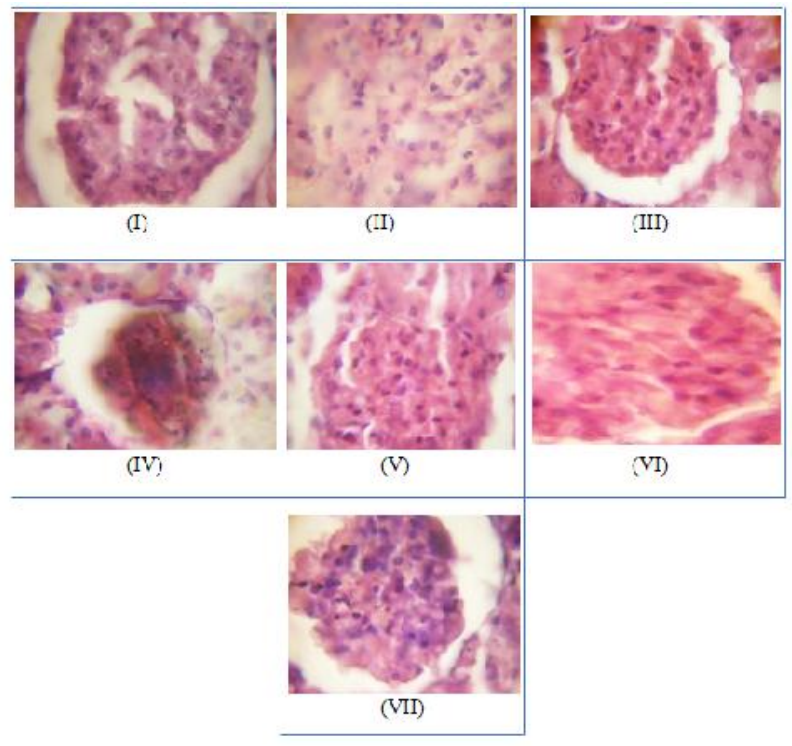

Group images showing the histopathology of kidney in experimental rats after $\mathbf{4 0}$ days treatment

Group (I): Normal control section shows the normal kidney showing healthy glomeruli and healthy cells having spherical shape and granulated cytoplasm architecture.
Group (II) Diabetic control section showing ruptured, destructive glomeruli and swelling ruptured cell wall and distorted cytoplasm with increased vacuoles.

Group (III) Diabetic +metformin (150mg/kg) section showing preserved many glomeruli and less swelling, regeneration of cell wall with decrease in vacuoles size.

Group (IV) Diabetic + H. spicatum (100 mg/kg) section showing intermediate preventive effect showing $40 \%$ of glomeruli in secure position $\&$ circular and oval shaped cells, less granular cytoplasm, regeneration of cell wall with less vacuoles size.

Group (V) Diabetic + H. spicatum (300 mg/kg) section significantly showing $60 \%$ of glomeruli in safe \& preventive effect showing oval shaped cells, granular cytoplasm, regenerated cell wall and intermediate vacuoles. Group (VI) Diabetic + H. spicatum $(500 \mathrm{mg} / \mathrm{kg}$ ) section showing $80 \%$ of glomeruli were safe \& preventive effect showing oval shaped cells, granular cytoplasm, regenerated cell wall and intermediate vacuoles.

Group (VII) Diabetic + [H. spicatum $(500 \mathrm{mg} / \mathrm{kg})+50 \%$ of metformin]section showing several glomeruli in safe \& preventive effect showing oval shaped cells, granular cytoplasm, regenerated cell wall and intermediate vacuoles.

\section{DISCUSSION}

The present investigation was aimed to evaluate the hypoglycaemic effects of ethanolic extracts of rhizomatous part of $H$. spicatum on STZ induced diabetes mediated metabolic alterations in rats. The presence of carbohydrates, steroids, polyphenols, triterpenes and alkaloids in ethanolic extract are visible in the preliminary phytochemical studies. The $\alpha$-amylase inhibitory activity in the ethanolic extract is most likely due to polar compounds and can be investigated further for isolating pure active compounds. Glucose lowering effects were found after oral administration of ethanolic extract in rats due to the presence of hypoglycaemic compounds i.e. flavonoids, terpenes or saponins that also require further investigation. All other biochemical parameters were found to support the hypoglycaemic activity of ethanolic extract [23, 24]. The potential of the extract to decrease cholesterol and triglyceride levels can help improve lipid metabolism in diabetics, which in turn will help to prevent diabetic complications. It seems that the extract either protected the cells from the toxic effect of STZ or the cells healed thereafter the initial injury. Therefore, $H$. spicatum had the potential of antidiabetic agent and exhibited significant improvement in blood glucose level, anti-oxidant as well as protection of renal cells so it may be used as an ayurvedic preparation or as adjuvant therapy.

\section{CONCLUSION}

In conclusion, our study showed that the Hedychium spicatum rhizome ethanolic extract posses an antidiabetic activity and nephroprotective in a dose dependent manner and being non toxic, widely used medicinal herb could be beneficial in ailment. This is an in-vitro, in-vivo study, the data of which can be used for further studies to reveal its intracellular mechanism of action and the compounds responsible for the pharmacological activity could be isolated and used therapeutically on human beings. 
International Journal of Pharma Research and Health Sciences, 2020; 8 (6): 3256-3261

\section{REFERENCES}

1. Tierney LM, McPhee SJ, Papadakis MA. Current Medical Diagnosis \& Treatment. International Edition. Lange Medical Books/McGraw-Hill, New York; 2002: 1203-15.

2. Anonymous. Diabetes now a global threat gets own day. Sunday Times of India 2006; 24:11

3. Schalkwijk GC, Stehouwer DC. Vascular complications in diabetes mellitus: the role of endothelial dysfunction. Clin Sci 2005; 109:143-59.

4. Alsaad KO, Herzenberg AM. Distinguishing Diabetic nephropathy from other causes of glomerulosclerosis: an update. J Clin Pathol 2007; 60: 18-26.

5. Marles RJ, Farnsworth NR. Antidiabetic plants and their active constituents. Phytomedicine 1995; 2:137-89.

6. Chopra RN, Nayar SL, Chopra LC. Glossary of Indian Medicinal Plants. Council of Scientific \& Industrial Research, 1986; New Delhi.

7. Srimal RC, Sharma SC, Tandon JS. Anti-inflammatory and other pharmacological effects of Hedychium spicatum (Buch-Hem). Indian J Pharmacol 1984; 16: 143-7.

8. Dhar ML, Dhar MM, Dhawan BN, Mehrotra BN, Srimal RC, Tandon JS. Screening of Indian medicinal plants for biological activity: Part IV. Indian J Exp Biol 1973; 11: 43-54.

9. Giri D, Tamta S, Pandey A. A review account on medicinal value of Hedychium spicatum buch-ham ex sm vulnerable medicinal plant. J Med Plants Res 2010; 2773-77.

10. Reddy PP, Rao RR, Shashidhar J, Sastry BS, Rao JM, Babu KS. Phytochemical investigation of labdane diterpenes from the rhizomes of Hedychium spicatum and their cytotoxic activity. Bioorg Med Chem Lett 2009; 19: 6078-81.

11. Khandelwal KR. Practical Pharmacognosy techniques and experiments. Pune: Nirali Prakashan; 2008; 8: 149-56.

12. Kokate CK. Practical Pharmacognosy. New Delhi: Vallabh Prakashan; 2005, 107-13.

13. Raman N. Phytochemical techniques. New India Publishing agency, Pitampura, New Delhi, India, 2006, 19-24.

14. Giancarlo S, Rosa LM, Nadjafi F, Francesco M. Hypoglycaemic activity of two spices extracts: Rhus coriaria L. and Bunium Persicum Boiss. Nat Prod Res 2006; 882-6.

15. Quershi S, Shah AH, Aeegel AM. Toxicity studies on Alpinia galanga and Curcuma longa. Planata med 1992; 58: 124-7.

16. Du Vigneaud V, Karr WG. Carbohydrate utilization, rat of disappearance of D-glucose from the blood. J Bio Chem 1925; 66: 281-300.
17. Burstein M, Scholnick HR, Morfin R. Rapid method for the isolation of lipoproteins from serum by precipitation with poh/anions. J Lipid Res 1970; 11:583-98.

18. Kono Y. Generation of superoxide radical during autoxidation of hydroxylamine and an assay for superoxide dismutase. Arch Biochem Biophys 1978; 189-95.

19. Montilla P, Barcos M, Munoz M, Castaneda I, Tunez. Red wine prevents brain oxidative stress and nephropathy in streptozotocin induced diabetic rats. $\mathrm{J}$ Biochem Mol Biol 2005; 539-44.

20. Makni M, Sefi M, Fetoui H, Garoui ME, Gargouri KN. Flax and pumpkin seeds mixture ameliorates diabetic nephropathy in rats. Food Chem Toxicol 2010; 2407-12.

21. Kumar BD, Mitra A, Manjunatha M. A comparative study of alpha-amylase inhibitory activities of common antidiabetic plants of Kharagpur 1 block. Int $\mathbf{J}$ Green Pharm 2010; 4:115-21.

22. Tattersall R. Targets of therapy for NIDDM. Diabetes Res Cli Pract 1995; 8: 549-55.

23. Randle PJ, Garland PB, Hales CN, Newsholme EA. The glucose fatty-acid cycle. Its role in insulin sensitivity and the metabolic disturbances of diabetes mellitus. Lancet 1963; 1:785-9.

\section{Conflict of Interest: None Source of Funding: Nil}

